\title{
Acute and Repeated Inhalation Toxicity of 1-Bromopropane in SD Rats
}

\author{
Hyeon-Yeong $\mathrm{KIM}^{1}$, Yong-Hyun ChUng ${ }^{1}$, Jae-Hwang Jeong ${ }^{1}$, Yong-Muk LeE', \\ Gil-Soo SUR ${ }^{2}$ and Jong-Koo KANG ${ }^{3}$ \\ ' Industrial Chemicals Research Center, Industrial Safety and Health Research Institute KISCO, Taejon, \\ ${ }^{2}$ Department of Chemical Engineering, Yeungnam University, Taegu, \\ ${ }^{3}$ College of Veterinary Medicine, Chungbuk National University, Cheongju, Korea
}

\begin{abstract}
Acute and Repeated Inhalation Toxicity of 1-Bromopropane in SD Rats: Hyeon-Yeong KIM et al. Industrial Chemicals Research Center, Industrial Health Research Institute, Korea-The acute and repeated inhalation toxicity of 1 bromopropane (1-BP) in SD rats were investigated. $\mathrm{LC}_{50}$ for four-hour exposure was $14,374 \mathrm{ppm}(95 \%$ confidence limit: $13,624-15,596 \mathrm{ppm}$ ). It was revealed to be irritating to the eyes with lacrimation in all fourhour exposure rats. No other abnormal clinical signs and gross findings related to the 1-BP exposure were observed. An experiment on repeated exposure to 0 , 50,300 , and $1,800 \mathrm{ppm}$ for six hrs/day, five days/week, for eight weeks was conducted. A decrease in body weights and increase in relative liver weight in both male and female rats were observed in the $1,800 \mathrm{ppm}$ exposure group ( $p<0.001$ vs. control group). No other significant changes in feed consumption, urinanalysis, hematology and serum biochemistry were observed. Histopathological examinations did not reveal any 1 BP-related changes.

(J Occup Health 1999; 41: 121-128)
\end{abstract}

Key words: 1-Bromopropane, Inhalation Toxicity, $\mathrm{LC}_{50}$

It is difficult to choose appropriate cleaning solvents for industrial use for many reasons such as toxicity and environmental unfriendliness. Up to now, halons have been used as cleaning solvents in the chemical and electronic industries. But they are now being replaced by alternatives because of their ozone-depleting and global warming characteristics"). In Korea, 2bromopropane (2-BP) has been used in the place of halons, but 2-BP was found to cause reproductive and

Received Sept 10, 1998; Accepted Mar 8, 1999

Correspondence to: H.-Y. Kim, Industrial Chemicals Research Center, Industrial Safety and Health Research Institute, 104-8 Moonji-dong, Yusong-ku, Taejon 305-380, Korea hematopoietic disorders in local workers exposed to solvents containing 2- $\mathrm{BP}^{2-6}$, which caused the Korean Ministry of Labor to establish the threshold limit value (TLV) for 2-BP in the workplace as $1 \mathrm{ppm}^{7}$. Owing to the toxicity of 2-BP, there has been a growing tendency to use 1-bromopropane (1-BP) as an alternative cleaning solvent to 2-BP. Even though there are no exact data on the total production of 1-BP, more than 100,000 tons of bromo compounds would have been produced annually in the U.S. alone ${ }^{83}$.

There are very few data available on the toxicity of 1$\mathrm{BP}$ and its established TLV in the workplace. $\mathrm{LC}_{50}$ for thirty-minute exposure was $253 \mathrm{~g} / \mathrm{kg}$ in rats $^{9)}$. Intraperitoneal $L_{50}$ of $1-\mathrm{BP}$ was reported to be $2.5 \mathrm{~g} / \mathrm{kg}$ in mice and $2.9 \mathrm{~g} / \mathrm{kg}$ in rats ${ }^{10}$. 1 - $\mathrm{BP}$ has a depressing action on the central nervous system (CNS) ${ }^{11)}$ and is reported to be irritating to the skin and eyes of mice"). Exposure of animals to the anesthetic concentration may result in injury to the lungs and liver ${ }^{11}$. Takeuchi et al. ${ }^{12}$ observed that the inhalation exposure of 1 - BP at 1,000 $\mathrm{ppm}$, eight-hours/day for 4 weeks, decreased the conduction velocity of the peripheral nerves in rats. They also observed peripheral nerve and CNS disorders in rats exposed to the same concentration for 5 to 6 weeks.

But the above inhalation toxicity of I-BP was not confirmed by other investigators. This study was carried out to assess the acute and repeated inhalation toxicity of 1-BP.

\section{Materials and Methods}

Chemicals: Chemicals used in this study were of reagent grade and purchased from commercial sources. 1-BP (Lot No. 7B2212) was obtained from Junsei Chemical Co., Ltd. (Tokyo, Japan).

Animals: Ten-week-old Sprague-Dawley (SD) rats (SPF grade) of both sexes were purchased from Dae Han Laboratory Animal Research center Co., Ltd. (Eumseong, 
Korea), After one weck of acclimation, 25 males (233.7 $\pm 32.1 \mathrm{~g})$ and 25 females $(186.3 \pm 6.9 \mathrm{~g})$ were chosen for the acute inhalation toxicity test, and 40 males (267.2 \pm $6.2 \mathrm{~g}$ ) and 40 females $(199.3 \pm 3.8 \mathrm{~g}$ ) were used for the repeated inhalation toxicity test. The rats were housed individually in wire-bottomed 5-straight stainless-steel cages placed in exposure chambers. The cages were maintained at $23 \pm 2{ }^{\circ} \mathrm{C}, 40-70 \%$ humidity, 12-h light/ 12-h dark cycle (light during 09:00-21:00), 11-15 times ventilation/h, and $5-15 \mathrm{mmAq}$ negative pressure. The rats were fed with the sterilized pellets (Jeil Feed Co., Ltd., Taejon, Korea) and sterilized tap water ad libitum through both the acclimation and observation periods.

Condition of chambers: Temperature, relative humidity, pressure and air ventilation were recorded by the environmental controller (Model No. ICS-20RG, Shibata Co., Ltd., Japan). Calibration of the concentration of 1-BP in the chambers was carried out with a standard Chemicals (Lot No. 7B2212, Junsei Chem. Co., Ltd., Japan), air pump (Model APN-110KV-1, Iwaki Co., Ltd., Japan), gas meter (Model DC-2A, Shinagawa Co., Ltd., Japan) and Teflon ${ }^{(B)}$ bags. The detection conditions for gas chromatography (GC) (Model GCS-14PFFS, Shimadzu, Japan) for 1-BP were as follows: detector, FID; column, silicon DC-200 15\% Chromosorb with mesh of $80 / 100$ and $0.5 \mathrm{~m}$ length; detector temperature, $150^{\circ} \mathrm{C}$; oven temperature, $100^{\circ} \mathrm{C}$; injector temperature, $150^{\circ} \mathrm{C}$; injection volume, $1 \mathrm{ml}$ of gas sample. The concentration of 1-BP in the chambers during the exposure was recorded with the GC every $15 \mathrm{~min}$.

Animal experimentation: Whole-body exposure chambers (Model No. SIS-20RG, Shibata Co., Ltd., Japan) including a gas generator (Model No. VG-4R, Shibata Co., Ltd., Japan) were used for exposure of the rats to 1-BP. For the acute inhalation toxicity test, 25 male and 25 female rats were entered. Animals of each sex were divided into five groups $(0,11,000,13,000$, 15,000 and $17,000 \mathrm{ppm}$ ). The rats were observed for two weeks after exposure, focusing on clinical appearances and death. The health status of the rats was observed daily for 14 days. At the end of the observation period, all the rats were sacrificed by $\mathrm{CO}_{2}$ gas anesthesia. Abnormal tissues were grossly taken and fixed in $10 \%$ neutral buffered formalin. These were embedded in paraffin, sectioned, and stained with hematoxylin-eosin. $\mathrm{LC}_{50}$ was determined by the Lithfiled-Wilcoxon method $^{(3)}$.

As a repeated inhalation experiment, a group of 10 male and female rats were exposed to 0 (control), 50 , 300 and $1,800 \mathrm{ppm}$ for six hrs a day, five days a week, for eight weeks. All the rats were inspected daily for clinical signs. Body weight and feed consumption were measured twice a week during the inhalation period. Urine samples were collected $24 \mathrm{~h}$ before the end of the experiment, and analyzed for red blood cells, white blood cells, bilirubin, urobilinogen, ketones, protein, nitrite, glucose, $\mathrm{pH}$, specific gravity and with a test strip (BioGen 10SGLM, Yeongdong Pharm Co., Ltd., Seoul, Korea). All the rats were anesthetized with dry ice $\left(\mathrm{CO}_{2}\right)$, and bled for hematology and biochemistry from the posterior vena cava. In hematological examinations, white blood cell, red blood cell, hemoglobin, hematocrit, mean corpuscular volume, mean corpuscular hemoglobin, mean corpuscular hemoglobin concentration, red cell volume distribution width, platelet count and mean platelet volume were determined with a hematological auto analyzer (Sysmex F-820, Japan). The differential leucocyte count was determined on the blood smears. In serum biochemical examinations, aspartate aminotransferase, alanine aminotransferase, alkaline phosphatase, glucose, blood urea nitrogen, protein, cholesterol, creatinine, sodium and total bilirubin were determined with a biochemical analyzer (TBA20FR, Japan). Organ weights were measured for the thymus, adrenal, testis, heart, lung, kidney, spleen, liver and brain. These tissues were taken and fixed in $10 \%$ neutral buffered formalin. The tissues were processed for standard paraffin embedding prior to sectioning at $5 \mu \mathrm{m}$ and stained with hematoxylin-Eosin and/or PAShematoxylin.

Statistical analysis: Two-way analysis of variance (ANOVA) and Duncan's multiple test were adopted for statistical testing.

\section{Results}

\section{Acute inhalation toxicity test}

Environmental and concentration monitoring: All the rats were housed at a temperature of $22.5-23.3^{\circ} \mathrm{C}$, a relative humidity of $43.8-65.3 \%$, a pressure of $-9.2-$

- $10.2 \mathrm{mmAq}$, and air ventilation of $196.7-201.0 \mathrm{l} / \mathrm{min}$ $(12 / \mathrm{h})$. These parameters were within the established value $\pm 4 \%$ (Table 1$)$.

Clinical findings: All treated groups were observed to have piloerection, decreased activity, ataxia and lacrimation within $1 \mathrm{~h}$ after exposure to $1-\mathrm{BP}$. As time went by, they did not respond to a noise level of about 100 phones. All male rats in the $11,000 \mathrm{ppm}$ group and $13,000 \mathrm{ppm}$ group survived the experiment, but two male rats in the $15,000 \mathrm{ppm}$ group were dead within $6 \mathrm{~h}$. The same results were observed in female rats in the 11,000 ppm group, but one female rat in the $13,000 \mathrm{ppm}$ group was dead within $12 \mathrm{~h}$. Four female rats in the 15,000 ppm group were dead within $24 \mathrm{~h}$. All surviving rats recovered to the normal condition after $24 \mathrm{~h}$.

Necropsy findings: There were no gross pathological findings in any of the animals in the experiment.

Histopathological findings: Some treated rats showed cytoplasmic vacuolation in the hepatocytes around the central veins, but without dose-dependency. No other specific histopathological findings were observed in the 
Table 1. Concentration of 1-BP during exposure in acute inhalation toxicity study

\begin{tabular}{lcccc}
\hline \multirow{2}{*}{ Groups } & \multicolumn{4}{c}{ Concentration (ppm) } \\
\cline { 2 - 5 } & Establishment & Upper & Lower & Mean \pm SD \\
\hline Group 1 & 11,000 & $11,147.5$ & $10,392.5$ & $10,909.4 \pm 185.99$ \\
Group 2 & 13,000 & $13,221.2$ & $12,855.5$ & $13,013.2 \pm 104.23$ \\
Group 3 & 15,000 & $15,565.7$ & $14,498.3$ & $15,129.3 \pm 383.92$ \\
Group 4 & 17,000 & $17,704.9$ & $16,297.2$ & $17,086.1 \pm 587.08$ \\
\hline
\end{tabular}

Table 2. Effects of concentration of 1-BP on mortality in SD rats

\begin{tabular}{|c|c|c|c|c|c|c|c|}
\hline \multirow{2}{*}{$\begin{array}{l}\text { Exposure } \\
\text { Groups }\end{array}$} & \multirow{2}{*}{$\begin{array}{l}\text { Concentration } \\
(\text { Mean } \pm \mathrm{SD})\end{array}$} & \multicolumn{2}{|c|}{ No. of rats } & \multicolumn{3}{|c|}{ No. of deaths } & \multirow{2}{*}{$\begin{array}{c}\text { Total } \\
\text { Mortality (\%) }\end{array}$} \\
\hline & & male & female & male & female & Total & \\
\hline Control & - & 5 & 5 & 0 & 0 & 0 & 0 \\
\hline Group 1 & $10,909.4 \pm 185.99$ & 5 & 5 & 0 & 0 & 0 & 0 \\
\hline Group 2 & $13,013.2 \pm 104.23$ & 5 & 5 & 0 & 1 & (1) & 10 \\
\hline Group 3 & $15,129.3 \pm 383.92$ & 5 & 5 & 2 & 4 & (6) & 60 \\
\hline Group 4 & $17,086.1 \pm 587.08$ & 5 & 5 & 5 & 5 & (10) & 100 \\
\hline
\end{tabular}

Table 3. Environmental conditions in the inhalation chamber during repeated exposure

\begin{tabular}{lccrr}
\hline \multicolumn{1}{c}{ Items } & $\begin{array}{c}\text { Chamber 0 } \\
\text { (Control) }\end{array}$ & $\begin{array}{c}\text { Chamber 1 } \\
(50 \mathrm{ppm})\end{array}$ & $\begin{array}{c}\text { Chamber 2 } \\
(300 \mathrm{ppm})\end{array}$ & \multicolumn{1}{c}{$\begin{array}{c}\text { Chamber 3 } \\
(1,800 \mathrm{ppm})\end{array}$} \\
\hline $\mathrm{T}\left({ }^{\circ} \mathrm{C}\right)$ & $22.9 \pm 1.23$ & $22.5 \pm 1.21$ & $22.8 \pm 1.32$ & $23.3 \pm 1.28$ \\
$\mathrm{RH}(\%)$ & $45.5 \pm 6.46$ & $44.8 \pm 6.52$ & $44.8 \pm 6.13$ & $50.2 \pm 1.80$ \\
$\mathrm{P}\left(\mathrm{mmH}{ }_{2} \mathrm{O}\right)$ & $-9.2 \pm 0.22$ & $-9.9 \pm 0.21$ & $-9.7 \pm 0.34$ & $302.6 \pm 10.10$ \\
$\mathrm{R}(\mathrm{L} / \mathrm{min})$ & $199.7 \pm 1.17$ & $201.0 \pm 1.17$ & $196.7 \pm 1.33$ & $1,803.4 \pm 39.84$ \\
\hline
\end{tabular}

T: Temperature, RH: Relative Humidity, P: Pressure, R: Flow Rate. All data values are expressed as the total mean (for 8 weeks) $\pm S D$.

treated groups when compared with the control group.

Median lethal concentration $\left(L C_{50}\right): \mathrm{LC}_{50}(4 \mathrm{~h})$ of 1 BP was 14,374 ppm (95\% confidence limit: 13,624$15,596 \mathrm{ppm}$ ). The lowest lethal concentration (LCLo) was lower than $11,833 \mathrm{ppm}$ (95\% confidence limit: $7,829-13,033 \mathrm{ppm}$ ) and the concentration 100 percent kill $\left(\mathrm{LC}_{100}\right)$ was higher than $18,186 \mathrm{ppm}(95 \%$ confidence limit: 16,616-26,632 ppm) (Table 2).

\section{Repeated inhalation toxicity test}

Environmental monitoring in chambers: Temperature, relative humidity, pressure, air ventilation and illumination cycle in the inhalation chambers were measured under the OECD guidelines for environmental control and are shown in Table 3. These parameters were within the established value of $4 \%$ (Table 4 ).

Clinical findings: $1,800 \mathrm{ppm}$ treated groups were observed to show decreased activity and mild ataxia after
$1 \mathrm{~h}$ exposure to $1-\mathrm{BP}$, but they recovered within $1 \mathrm{~h}$ after termination daily inhalation test.

Body weights: Changes in body weight during the whole inhalation period are shown in Fig. 1 (for males) and in Fig. 2 (for females). There was a statistically significant decrease in body weight in male rats from 5 weeks ( 39 days) inhalation of $1-B P(p<0.05)$, and in female rats from 4 weeks ( 27 days) inhalation of 1-BP $(0.01<\mathrm{p}<0.05)$.

Feed consumption: There were no statistically significant changes between the control group and the treated groups in feed consumption (data not shown).

Urinalysis: The level of urobilinogen was decreased in male rats in the $1,800 \mathrm{ppm}$ group $(\mathrm{p}<0.05)$, but increased in female rats in the $300 \mathrm{ppm}$ group and the $1,800 \mathrm{ppm}$ group $(p<0.001)$. The level of bilirubin was increased in female rats in the $1,800 \mathrm{ppm}$ group ( $\mathrm{p}<0.001$ ). There were statistically significant increases in ketone 
Table 4. Concentration of 1-BP during exposure in repcated inhalation toxicity study

\begin{tabular}{lcccc}
\hline \multirow{2}{*}{ Groups } & \multicolumn{4}{c}{ Concentration (ppm) } \\
\cline { 2 - 5 } & Establishment & Upper & Lower & Mean \pm SD \\
\hline Group 1 & - & 0 & 0 & $0.0 \pm 0.00$ \\
Group 2 & 50 & 52.7 & 46.6 & $50.2 \pm 1.80$ \\
Group 3 & 300 & 320.2 & 286.7 & $302.6 \pm 10.10$ \\
Group 4 & 1,800 & $1,852.5$ & $1,756.9$ & $1,803.4 \pm 39.84$ \\
\hline
\end{tabular}

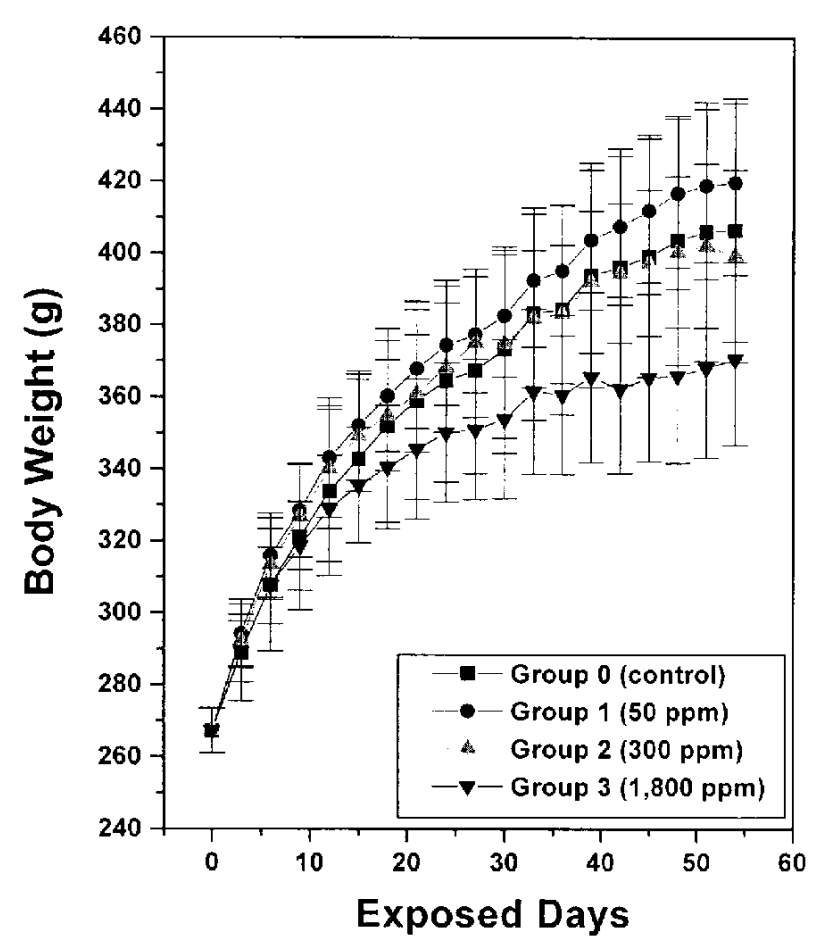

Fig. 1. Change in body weights of male SD rats that inhaled 1bromopropane during the experiment.

bodies in both sexes in the 1,800 ppm group $(p<0.05)$ and in females in the $300 \mathrm{ppm}$ group $(\mathrm{p}<0.05)$. The level of leucocytes was increased significantly in females in the 1,800 ppm group ( $<<0.05)$.

Necropsy findings: There were no gross pathological findings in any of the animals.

Organ weights: The relative organ weights (organ weight $/ 100 \mathrm{~g}$ body weight) are summarized in Table 5 for the males and Table 6 for the females. The weights of liver and brain in male rats were increased dosedependently. The weights of testis were increased in the 1,800 ppm group ( $p<0.01$ ). The weights of liver, kidney and ovary in female rats were significantly increased in the $1,800 \mathrm{ppm}$ group, at the level of $\mathrm{p}<0.001, \mathrm{p}<0.01$, and $\mathrm{p}<0.01$, respectively.

Hematology: Table 7 shows that the white blood cell

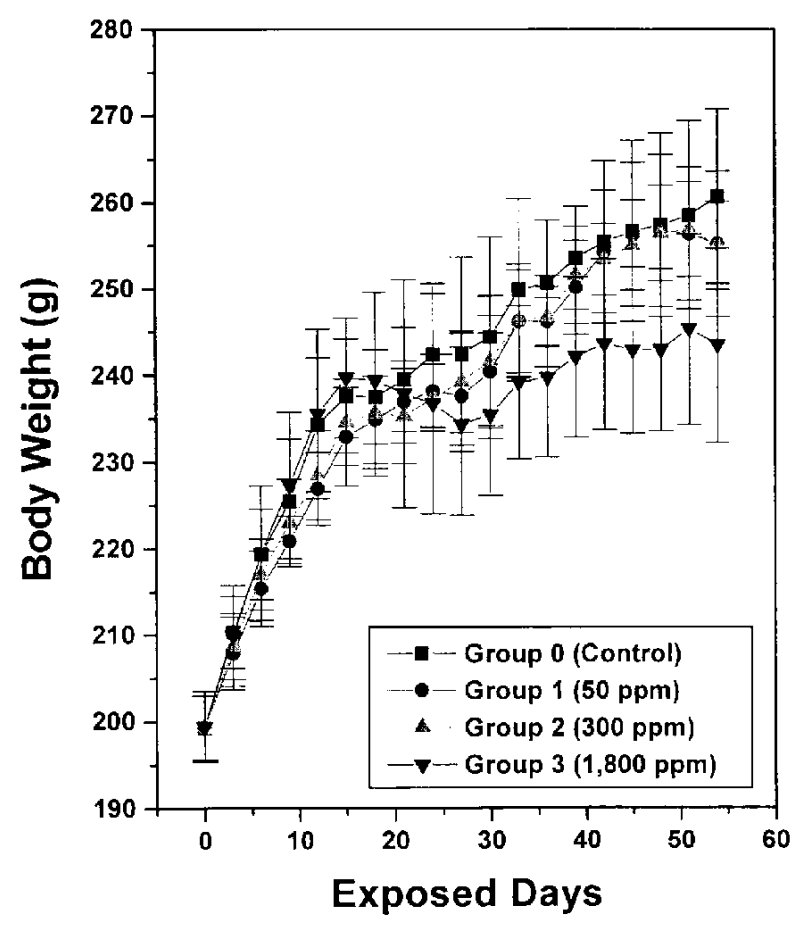

Fig. 2. Change in body weights of female SD rats that inhaled 1-bromopropane during the experiment.

count ( $p<0.01)$, red blood cell count $(\mathrm{p}<0.01)$, hematochrit $(p<0.01)$ and mean corpuscular volume $(p<0.05)$ significantly decreased, but the mean corpuscular hemoglobin $(p<0.01)$ and mean corpuscular hemoglobin concentration $(\mathrm{p}<0.001)$ significantly increased in the males in the $1,800 \mathrm{ppm}$ group. In the males in the 50 ppm group, white blood cell and platelets significantly decreased, whereas the mean corpuscular volume, mean corpuscular hemoglobin concentration and red cell volume distribution width significantly increased. Table 8 shows that the mean corpuscular volume significantly decreased $(p<0.05$ ) in females in the 300 ppm group and decreased $(p<0.001)$ in females in the 1,800 ppm group. The red cell volume distribution width significantly decreased $(p<0.001)$ in females in the 50 ppm and 1,800 ppm groups. 
Table 5. Relative organ weights of male SD rats after inhalation of 1-BP for 8 weeks

Unit: $\mathrm{mg} / 100 \mathrm{~g} \mathrm{B.W}$.

\begin{tabular}{lcccc}
\hline Organ & $\begin{array}{c}\text { Group 0 } \\
(\text { Control })\end{array}$ & $\begin{array}{c}\text { Group 1 } \\
(50 \mathrm{ppm})\end{array}$ & $\begin{array}{c}\text { Group 2 } \\
(300 \mathrm{ppm})\end{array}$ & $\begin{array}{c}\text { Group 3 } \\
(1,800 \mathrm{ppm})\end{array}$ \\
Thymus & $114.1 \pm 15.28$ & $108.0 \pm 20.87$ & $95.8 \pm 25.51$ & $100.4 \pm 24.22$ \\
Adrenal R & $7.9 \pm 1.62$ & $9.1 \pm 1.76$ & $10.2 \pm 2.71^{*}$ & $9.3 \pm 2.54$ \\
Adrenal L & $7.5 \pm 1.45$ & $9.8 \pm 2.76^{*}$ & $10.3 \pm 1.19^{* *}$ & $9.3 \pm 2.04^{*}$ \\
Testis R & $444.2 \pm 22.17$ & $422.5 \pm 28.80$ & $459.3 \pm 54.80$ & $471.3 \pm 26.52^{*}$ \\
Testis L & $442.1 \pm 27.18$ & $423.1 \pm 29.76$ & $463.1 \pm 50.27$ & $476.1 \pm 31.22^{* *}$ \\
Heart & $338.9 \pm 27.16$ & $326.2 \pm 16.89$ & $348.1 \pm 23.09$ & $348.2 \pm 15.38$ \\
Lung R & $167.9 \pm 23.35$ & $151.0 \pm 11.77$ & $165.3 \pm 11.66$ & $179.3 \pm 30.38$ \\
Lung L & $322.0 \pm 32.03$ & $285.0 \pm 34.18$ & $323.0 \pm 20.47$ & $321.8 \pm 46.31$ \\
Kidncy R & $330.8 \pm 19.64$ & $326.4 \pm 28.07$ & $334.9 \pm 17.66$ & $371.2 \pm 17.12^{* *}$ \\
Kidney L & $331.0 \pm 32.03$ & $346.5 \pm 22.66$ & $350.3 \pm 26.65$ & $359.7 \pm 16.98$ \\
Spleen & $181.4 \pm 17.96$ & $175.1 \pm 18.60$ & $189.3 \pm 14.51$ & $176.0 \pm 16.60$ \\
Liver & $2,567.4 \pm 110.80$ & $2,628.7 \pm 203.60$ & $2,746.8 \pm 197.70^{*}$ & $3,011.1 \pm 133.90^{* * *}$ \\
Brain & $453.6 \pm 37.96$ & $458.0 \pm 48.68$ & $505.1 \pm 31.73^{*}$ & $520.9 \pm 31.72^{* *}$ \\
\hline
\end{tabular}

All values are the mean \pm SD. Significant differences as compared with the control: ${ }^{*} \mathrm{p}<0.05$; ${ }^{* *} \mathrm{p}<0.01 ; * * * \mathrm{p}<0.001$.

Table 6. Relative organ weights of female SD rats after inhalation of 1-BP for 8 weeks

\begin{tabular}{lcccc}
\multicolumn{5}{c}{} \\
Organ & $\begin{array}{c}\text { Group 0 } \\
\text { (Control) }\end{array}$ & $\begin{array}{c}\text { Group 1 } \\
(50 \mathrm{ppm})\end{array}$ & $\begin{array}{c}\text { Group } 2 \\
(300 \mathrm{ppm})\end{array}$ & $\begin{array}{c}\text { Group } 3 \\
(1,800 \mathrm{ppm})\end{array}$ \\
\hline Thymus & $130.5 \pm 13.58$ & $107.6 \pm 15.56^{*}$ & $116.5 \pm 17.59$ & $107.6 \pm 21.78^{*}$ \\
Adrenal R & $18.7 \pm 2.31$ & $16.9 \pm 1.81$ & $17.6 \pm 2.84$ & $17.4 \pm 3.37$ \\
Adrenal L & $17.5 \pm 2.19$ & $19.5 \pm 1.82$ & $18.3 \pm 1.58$ & $17.8 \pm 3.08$ \\
Ovary R & $29.2 \pm 5.83$ & $29.7 \pm 5.79$ & $30.3 \pm 3.10$ & $37.0 \pm 6.68^{*}$ \\
Ovary L & $27.0 \pm 4.88$ & $29.9 \pm 3.99$ & $30.4 \pm 4.39$ & $35.0 \pm 6.75^{* *}$ \\
Heart & $360.9 \pm 22.37$ & $363.4 \pm 28.48$ & $360.8 \pm 29.13$ & $382.9 \pm 41.34$ \\
Lung R & $219.7 \pm 19.32$ & $207.6 \pm 24.11$ & $223.3 \pm 22.70$ & $230.5 \pm 22.82$ \\
Lung L & $436.2 \pm 51.03$ & $414.7 \pm 14.23$ & $407.8 \pm 20.67$ & $439.8 \pm 34.33$ \\
Kidney R & $337.2 \pm 21.80$ & $316.7 \pm 18.68$ & $336.1 \pm 23.46$ & $371.6 \pm 23.11^{*}$ \\
Kidney L & $314.2 \pm 48.62$ & $310.5 \pm 25.16$ & $323.9 \pm 26.57$ & $358.3 \pm 19.71^{* *}$ \\
Spleen & $214.4 \pm 23.00$ & $208.4 \pm 22.22$ & $219.6 \pm 24.36$ & $237.9 \pm 31.27$ \\
Liver & $2,391.8 \pm 60.30$ & $2,374.2 \pm 70.60$ & $2,454.0 \pm 200.50$ & $3,067.7 \pm 121.30^{* * *}$ \\
Brain & $756.7 \pm 34.75$ & $711.0 \pm 26.75$ & $677.8 \pm 38.39$ & $722.0 \pm 36.60$ \\
\hline
\end{tabular}

All values are the mean $\pm \mathrm{SD}$. Significant differences as compared with the control: ${ }^{*} \mathrm{p}<0.05$; ${ }^{* *} \mathrm{p}<0.01 ;{ }^{* * *} \mathrm{p}<0.001$.

Blood biochemistry: Table 9 shows the biochemical serum values in male rats after inhalation of 1-BP for 8 weeks. Table 10 shows those in female rats. The levels of alanine transferase, aspartate aminotransferase and lactate dehydrogenase in the males were significantly decreased in the some treated groups. In the females there was also a significant decrease in the level of alanine transferase.

Histopathological findings: All treated rats showed signs of cytoplasmic vacuolation in the hepatocytes around the central veins, but without dose-dependency. Tubular casts in kidney were observed in females in the $1,800 \mathrm{ppm}$ group. No other tissues in any of the treated groups showed signs of toxicologic lesions.

\section{Discussions}

1-BP has a low ozone-depleting potential (0.006) and global warming potential $(0.0001)$. In addition, it 
Table 7. Hematological values in male SD rats after inhalation of 1-BP for 8 weeks

\begin{tabular}{lcccc}
\hline Items & $\begin{array}{c}\text { Group 0 } \\
(\text { Control })\end{array}$ & $\begin{array}{c}\text { Group 1 } \\
(50 \mathrm{ppm})\end{array}$ & $\begin{array}{c}\text { Group 2 } \\
(300 \mathrm{ppm})\end{array}$ & $\begin{array}{c}\text { Group 3 } \\
(1,800 \mathrm{ppm})\end{array}$ \\
\cline { 2 - 5 } WBC & $9.9 \pm 2.29$ & $7.5 \pm 1.43^{*}$ & $8.2 \pm 2.22$ & $7.1 \pm 1.42^{* *}$ \\
RBC & $7.9 \pm 0.33$ & $7.2 \pm 0.79$ & $7.6 \pm 0.53$ & $7.3 \pm 0.39^{* *}$ \\
HGB & $15.9 \pm 0.43$ & $15.9 \pm 0.86$ & $15.7 \pm 0.48$ & $15.8 \pm 0.38$ \\
HCT & $46.6 \pm 3.96$ & $43.9 \pm 3.59$ & $43.7 \pm 2.43$ & $40.8 \pm 2.11^{* *}$ \\
MCV & $58.1 \pm 2.54$ & $61.5 \pm 2.96^{* *}$ & $57.4 \pm 1.07$ & $56.1 \pm 0.92^{*}$ \\
MCH & $20.2 \pm 0.90$ & $22.3 \pm 1.54^{* *}$ & $20.7 \pm 0.92$ & $21.8 \pm 1.01^{* *}$ \\
MCHC & $34.9 \pm 1.65$ & $36.2 \pm 1.33^{*}$ & $36.0 \pm 1.08$ & $38.9 \pm 1.78^{* * *}$ \\
PLT & $953.5 \pm 84.1$ & $873.5 \pm 71.0^{*}$ & $894.2 \pm 153.4$ & $926.3 \pm 84.4$ \\
RDW & $12.9 \pm 0.68$ & $14.9 \pm 0.99^{* * *}$ & $13.2 \pm 0.84$ & $12.1 \pm 0.49$ \\
PDW & $8.1 \pm 0.63$ & $8.4 \pm 0.39$ & $7.8 \pm 0.49$ & $7.8 \pm 0.26$ \\
MPV & $7.8 \pm 0.40$ & $8.1 \pm 0.33$ & $7.8 \pm 0.36$ & $7.8 \pm 0.20$ \\
\% LYM & $89.6 \pm 5.91$ & $89.7 \pm 2.83$ & $91.4 \pm 3.43$ & $87.7 \pm 4.72$ \\
\% NEU & $10.0 \pm 6.02$ & $9.7 \pm 2.54$ & $8.1 \pm 3.41$ & $11.4 \pm 4.77$ \\
\% EOS & $0.3 \pm 0.48$ & $0.5 \pm 0.85$ & $0.4 \pm 0.53$ & $0.8 \pm 0.63$ \\
\% MONO & 0 & 0 & 0 & $0.1 \pm 0.32$ \\
\hline
\end{tabular}

All values are the mean $\pm S D$. Significant differences as compared with the control: $* p<0.05$; ${ }^{* *} \mathrm{p}<0.01 ; * * * \mathrm{p}<0.001$.

WBC, white blood cell count $\left(10^{3} / \mathrm{mm}^{3}\right)$; RBC, red blood cell count $\left(10^{6} / \mathrm{mm}^{3}\right)$; HGB, hemoglobin $(\mathrm{g} / \mathrm{d} l)$; HCT, hematocrit (\%); MCV, mean corpuscular volume $\left(\mu^{3}\right)$; $\mathrm{MCH}$, mean corpuscular hemoglobin (pg); MCHC, mean corpuscular hemoglobin concentration (\%); PLT, platelets $\left(10^{3} / \mathrm{mm}^{3}\right)$; RDW, red cell volume distribution width (\%); PDW, platelet volume distribution width (\%); MPV, mean platelet volume $\left(\mu^{3}\right)$; \%NEU, \% of neutrophils; \%LYM, \% of lymphocytes; \% EOS, \% of eosinophils; \% MONO, \% of monocytes.

Table 8. Hematological values in female SD rats after inhalation of 1-BP for 8 weeks

\begin{tabular}{lccccc}
\hline Items & & $\begin{array}{c}\text { Group 0 } \\
\text { (Control) }\end{array}$ & $\begin{array}{c}\text { Group 1 } \\
(50 \mathrm{ppm})\end{array}$ & $\begin{array}{c}\text { Group 2 } \\
(300 \mathrm{ppm})\end{array}$ & $\begin{array}{c}\text { Group 3 } \\
(1,800 \mathrm{ppm})\end{array}$ \\
\cline { 1 - 3 } \cline { 5 - 7 } WBC & & $4.7 \pm 1.22$ & $5.4 \pm 0.91$ & $5.1 \pm 1.44$ & $5.4 \pm 1.12$ \\
RBC & & $7.3 \pm 0.52$ & $7.4 \pm 0.58$ & $7.2 \pm 0.34$ & $7.4 \pm 0.49$ \\
HGB & & $15.5 \pm 0.63$ & $15.5 \pm 0.97$ & $15.3 \pm 0.89$ & $15.3 \pm 0.79$ \\
HCT & & $44.1 \pm 2.74$ & $44.0 \pm 3.06$ & $42.8 \pm 1.89$ & $42.5 \pm 2.46$ \\
MCV & & $60.4 \pm 1.24$ & $59.6 \pm 1.03$ & $59.4 \pm 1.25 *$ & $57.3 \pm 1.21^{* * *}$ \\
MCH & & $21.3 \pm 0.89$ & $21.0 \pm 0.98$ & $21.3 \pm 1.28$ & $20.7 \pm 1.82$ \\
MCHC & & $35.2 \pm 1.04$ & $35.2 \pm 1.21$ & $35.8 \pm 1.66$ & $36.2 \pm 3.03$ \\
PLT & & $972.9 \pm 58.1$ & $913.6 \pm 64.9$ & $964.1 \pm 80.8$ & $928.9 \pm 78.9$ \\
RDW & & $13.3 \pm 0.50$ & $11.8 \pm 0.51^{* * *}$ & $13.4 \pm 0.76$ & $11.4 \pm 0.48^{* * *}$ \\
PDW & $7.9 \pm 0.24$ & $7.8 \pm 0.30$ & $7.9 \pm 0.33$ & $7.8 \pm 0.42$ \\
MPV & $7.8 \pm 0.15$ & $7.8 \pm 0.25$ & $7.8 \pm 0.31$ & $7.8 \pm 0.22$ \\
\% LYM & $92.2 \pm 3.58$ & $94.6 \pm 2.41$ & $90.3 \pm 3.34$ & $89.0 \pm 5.31$ \\
\% NEU & $7.0 \pm 3.33$ & $4.5 \pm 2.17$ & $8.8 \pm 3.05$ & $9.5 \pm 5.28$ \\
\% EOS & $0.8 \pm 1.14$ & $0.6 \pm 0.84$ & $0.9 \pm 0.99$ & $1.5 \pm 1.08$ \\
\% MONO & 0 & 0 & & 0 & 0 \\
\hline
\end{tabular}

All values are the mean \pm SD. Significant differences as compared with the control: ${ }^{*} \mathrm{p}<0.05$; ${ }^{* *} p<0.01 ; * * * p<0.001$.

WBC, white blood cell count $\left(10^{3} / \mathrm{mm}^{3}\right)$; RBC, red blood cell count $\left(10^{6} / \mathrm{mm}^{3}\right)$; HGB, hemoglobin ( $\mathrm{g} / \mathrm{d} l)$; HCT, hematocrit (\%); MCV, mean corpuscular volume $\left(\mu^{3}\right) ; \mathrm{MCH}$, mean corpuscular hemoglobin (pg); $\mathrm{MCHC}$, mean corpuscular hemoglobin concentration (\%); PLT, platelets $\left(10^{3} / \mathrm{mm}^{3}\right)$; RDW, red cell volume distribution width (\%); PDW, platelet volume distribution width (\%); MPV, mean platelet volume $\left(\mu^{3}\right) ; \%$ NEU, $\%$ of neutrophils; $\%$ LYM, \% of lymphocytes; \% EOS, \% of eosinophils; \% MONO, \% of monocytes. 
Table 9. Biochemical serum values in male SD rats after inhalation of 1-BP for 8 weeks

\begin{tabular}{lcccc}
\hline Items & $\begin{array}{c}\text { Group 0 } \\
(\text { Control })\end{array}$ & $\begin{array}{c}\text { Group 1 } \\
(50 \mathrm{ppm})\end{array}$ & $\begin{array}{c}\text { Group 2 } \\
(300 \mathrm{ppm})\end{array}$ & $\begin{array}{c}\text { Group } 3 \\
(1,800 \mathrm{ppm})\end{array}$ \\
\hline TP & $6.7 \pm 0.44$ & $6.5 \pm 0.42$ & $6.5 \pm 0.38$ & $6.2 \pm 0.68$ \\
BUN & $16.0 \pm 1.46$ & $15.2 \pm 1.72$ & $14.5 \pm 0.91^{*}$ & $15.8 \pm 2.17$ \\
CRTN & $0.6 \pm 0.11$ & $0.6 \pm 0.03$ & $0.6 \pm 0.03$ & $0.6 \pm 0.10$ \\
T-BIL & $0.2 \pm 0.16$ & $0.2 \pm 0.12$ & $0.2 \pm 0.10$ & $0.2 \pm 0.11$ \\
GLU & $163.1 \pm 20.90$ & $154.2 \pm 28.70$ & $164.5 \pm 14.20$ & $164.3 \pm 11.80$ \\
T-CHO & $88.3 \pm 17.70$ & $92.9 \pm 12.30$ & $95.6 \pm 17.90$ & $81.2 \pm 18.20$ \\
AST & $112.8 \pm 10.70$ & $103.0 \pm 28.90$ & $81.4 \pm 17.90^{* * *}$ & $80.3 \pm 9.63^{* * * *}$ \\
ALT & $44.0 \pm 5.73$ & $34.7 \pm 6.25^{*}$ & $29.7 \pm 8.56^{* * *}$ & $23.2 \pm 6.78^{* * *}$ \\
LDH & $1,441.4 \pm 623.70$ & $1,168.7 \pm 406.10$ & $992.4 \pm 657.90$ & $1,067.9 \pm 269.50^{*}$ \\
ALP & $214.9 \pm 31.60$ & $200.8 \pm 35.00$ & $180.5 \pm 39.10$ & $171.1 \pm 54.00$
\end{tabular}

All values are the mean $\pm S D$. Significant differences as compared with the control: $* p<0.05$; $* * \mathrm{p}<0.01 ; * * * \mathrm{p}<0.001$.

$\mathrm{TP}$, total protein $(\mathrm{mg} / \mathrm{d} l)$; BUN, urea nitrogen in blood $(\mathrm{mg} / \mathrm{d} l) ; \mathrm{CRTN}$, creatinine $(\mathrm{mg} / \mathrm{d} l) ; \mathrm{T}-\mathrm{BIL}$, total bilirubin (mg/d $l$; GLU, glucose ( $\mathrm{mg} / \mathrm{d} l) ; \mathrm{T}-\mathrm{CHO}$, total cholesterol (mmol/l); AST, aspartate aminotransferase $(\mu / l)$; ALT, alanine aminotransferase $(\mu / l)$; LDH, lactate dehydrogenase $(\mu / l)$; ALP, alkaline phosphatase $(\mu l)$.

Table 10. Biochemical serum values in female SD rats after inhalation of 1-BP for 8 weeks

\begin{tabular}{lcccc}
\hline Items & $\begin{array}{c}\text { Group 0 } \\
\text { (Control) }\end{array}$ & $\begin{array}{c}\text { Group 1 } \\
(50 \mathrm{ppm})\end{array}$ & $\begin{array}{c}\text { Group 2 } \\
(300 \mathrm{ppm})\end{array}$ & $\begin{array}{c}\text { Group 3 } \\
(1,800 \mathrm{ppm})\end{array}$ \\
\hline TP & $6.4 \pm 0.22$ & $6.5 \pm 0.14$ & $6.0 \pm 0.71$ & $6.5 \pm 0.74$ \\
BUN & $15.1 \pm 1.80$ & $16.7 \pm 2.21$ & $16.0 \pm 2.54$ & $15.4 \pm 2.45$ \\
CRTN & $0.7 \pm 0.02$ & $0.7 \pm 0.03$ & $0.7 \pm 0.03$ & $0.6 \pm 0.07 * *$ \\
T-BIL & $0.3 \pm 0.08$ & $0.3 \pm 0.16$ & $0.3 \pm 0.11$ & $0.21 \pm 0.08 *$ \\
GLU & $136.1 \pm 23.70$ & $132.4 \pm 30.90$ & $160.4 \pm 18.30^{*}$ & $144.0 \pm 17.10$ \\
T-CHO & $102.2 \pm 25.40$ & $88.0 \pm 14.20$ & $81.4 \pm 15.40^{*}$ & $84.9 \pm 33.80$ \\
AST & $86.7 \pm 17.60$ & $100.1 \pm 12.90$ & $78.7 \pm 20.10$ & $83.0 \pm 24.40$ \\
ALT & $39.8 \pm 19.10$ & $29.1 \pm 8.67$ & $25.4 \pm 5.89^{*}$ & $22.6 \pm 3.09^{*}$ \\
LDH & $1,023.1 \pm 164.70$ & $1,037.5 \pm 361.10$ & $759.9 \pm 205.80^{* *}$ & $1,126.9 \pm 189.20$ \\
ALP & $135.4 \pm 21.30$ & $140.6 \pm 40.40$ & $135.6 \pm 33.80$ & $125.5 \pm 24.60$ \\
\hline
\end{tabular}

All values are the mean $\pm \mathrm{SD}$. Significant differences as compared with the control: ${ }^{*} \mathrm{p}<0.05$; ${ }^{* *} \mathrm{p}<0.01 ;{ }^{* * *} \mathrm{p}<0.001$.

TP, total protein $(\mathrm{mg} / \mathrm{d} l)$; BUN, urea nitrogen in blood $(\mathrm{mg} / \mathrm{d} l)$; CRTN, creatinine $(\mathrm{mg} / \mathrm{d} l) ; \mathrm{T}$-BIL, total bilirubin (mg/dl); GLU, glucose ( $\mathrm{mg} / \mathrm{d} l)$; T-CHO, total cholesterol (mmol/l); AST, aspartate aminotransferase $(\mu / l)$; ALT, alanine aminotransferase $(\mu / l)$; LDH, lactate dehydrogenase $(\mu / l)$; ALP, alkaline phosphatase $(\mu / l)$.

has also good cleaning power ${ }^{(4)}$. Recently it has been used as an alternative cleaning solvent to $\mathrm{CFC}$, hydrochlorofluorocarbon (HCEC), 1,1,1-trichloroethane (TCE) and 2-BP, all of which were associated with environmental and toxicologic problems.

Five groups of rats inhaled $0,11,000 \mathrm{ppm}, 13,000 \mathrm{ppm}$, $15,000 \mathrm{ppm}$ and $17,000 \mathrm{ppm}$ of 1-BP in acute inhalation toxicity tests. The $\mathrm{LC}_{50}$ of 1-BP was estimated to be 14,374 ppm (95\% confidence limit: 13,624-15,596 ppm).
This is lower than the LC $_{50}$ of $2-B P(31,171 \mathrm{ppm})^{|5\rangle}$. 1$\mathrm{BP}$ was shown to cause eye irritation with lacrimation in all the treated groups. No other abnormal clinical signs were observed due to exposure to 1-BP in four-hour inhalation. Body weight was similar in the control and treated groups. Gross findings on necropsy revealed no evidence of specific toxicity related to the 1-BP. No specific toxicologic lesions were observed on histopathological examination. 
In repeated inhalation toxicity tests, no deaths occurred during the experiment. Clinical signs and gross findings on necropsy revealed no evidence of specific toxicity related to the 1-BP. Even though some items in treated groups were significantly different from those in the control group in urine biochemistry, hematology and blood biochemistry, they were mostly in the normal range. The relative organ weights of liver, the level of ALT, AST and $\mathrm{LDH}$, and the observation of the cytoplasmic vacuolation in the hepatocytes around the central veins in both sexes of rats in the $1,800 \mathrm{ppm}$ group appear to be related with the hepatotoxic effect of 1-BP, but which has no exposure effect relationship ${ }^{16.17)}$.

2-BP was reported to have specific reproductive and hematopoietic toxicity in both male and female SD rats after intraperitoneal injection, and in male Wistar rats after inhalation ${ }^{2-6)}$. 2-BP could also impair the bone marrow, resulting in pancytopenia ${ }^{5,6}$. In this experiment the relative weights of testis and ovary in the $1,800 \mathrm{ppm}$ 1-BP group were significantly increased, but there was no abnormality of testis or ovary in necropsy findings. 1-BP did not reveal specific lesions in testis or ovary histopathologically.

In conclusion, 1-BP was confirmed to have a low $\mathrm{LC}_{50}$ (4 h) of 14,374 ppm. 1-BP may be used as an alternative cleaning solvent in industry after getting specific and long-term toxicologic information on carcinogenicity and teratogenicity.

\section{References}

1) EPA's Stratopheric Protection Division. Ozone Depletion Glossary, EPA, 1996.

2) Takeuchi $Y$, Ichihara $G$ and Kamija $M$. A review on toxicity of 2-bromopropane: Mainly: Mainly on its reproductive toxicity. J Occup Health 1997; 39: 179191.

3) Yu IJ, Chung YH, Lim CH. Reproductive toxicity of 2-bromopropane in Sprague Dawley rats. Scand J Work
Environ Health 1997; 23: 281-288.

4) $\mathrm{Lim} \mathrm{CH}$, Maeng $\mathrm{SH}$, Lee JY. Effects of 2 bromopropane on the female reproductive function in Sprague-Dawley rats. Industrial Health 1997; 35: 278284.

5) Kim YH, Jung K, Hwang T, Jung G. Hematopoietic and reproductive hazards of Korean electronic workers exposed to solvents containing 2-bromopropane. Scand J Work Environ Health 1996; 22: 387-391.

6) Park JS, Kim Y, Park D, Choi K, Park S, Moon Y. An outbreak of hematopoietic and reproductive disorders due to solvents containing 2-bromopropane in an electronic factory, South Korea: Epidemiological survey. J Occup Health 1997; 39: 138-143.

7) The exposure criteria of chemical and physical factors. Korean Ministry of Labor 1998.

8) Chemical Week, The Chemical Week Buyers 1996.

9) Sax NI. Dangerous Properties of Industrial Materials, Van Nostrand Reinhold, New York, 1968: 923.

10) Clayton GD and Clayton FE (eds.). Patty's Industrial Hygiene and Toxicology, Volume 2A, 2B, 2C, Toxicology. 3rd ed. New York, John Wiley Sons, 19811982.

11) Irish DD. Aliphalic Halogenated Hydrocarbons, Industrial Hygiene and Toxicology, Vol. 2 ed., by Patty, F.A., Interscience, New York, 1962: 1249.

12) Takeuchi Y, Ichihara G, Kamijima M. Reproductive toxicity of 2-bromopropane and neurological toxicity of 1-bromopropane. Contents of the 71 th Annual Meeting of Japan Society for Occupational Health 1997; 39: A135.

13) Lichfield J, Wilcoxon F. A simplified method on evaluating dose-effect experiments. J Pharmacol Exp Therap 1949; 96: 99-113.

14) The chemical Daily Newspaper. Japan, Dec., 19, 1997.

15) Kim HY, Chung YH, Yi KH, Kim JG, Yu IJ. LC Lf $_{50}$ 2bromopropane. Industrial Health 1996; 34; 403-407.

16) Lee KY, Lee JS. Clinical pathological file. Medical cultural 1993.

17) Lee YS. Laboratory animal medicine. 1991. 